\title{
Relationship between balance and aerobic capacity in adolescent athletes
}

\author{
Cengiz TASKIN¹, Mine TASKIN², Faruk GUVEN³ \\ ${ }^{1}$ School of Physical Education and Sport, Batman University, Batman, Turkey. \\ ${ }^{2}$ Institute of Health Sciences, Dumlupinar University, Kütahya, Turkey. \\ ${ }^{3}$ School of Physical Education and Sport, Kilis University, Kilis, Turkey. \\ Address correspondence to C. Taskin, cengiz.taskin@batman .edu.tr
}

\begin{abstract}
The aim of study was to examine relationship between balance and aerobic capacity in adolescent athletes. Total fifty athletes that is twenty five female and twenty five male participated as volunteer. Male athletes (age means; $17.12 \pm 0.83$ years, height means; $172.28 \pm 7.66 \mathrm{~cm}$, body weight means; $64.96 \pm 9.21 \mathrm{~kg}$ ). Female athletes (age means; $16.80 \pm 0.82$ years, height means; $162.36 \pm 6.24 \mathrm{~cm}$, body weight means; $53.76 \pm 5.88 \mathrm{~kg}$ ). Athletes completed the 20 -meter shuttle run test for aerobic capacity and flamingo balance test for balance. In generally, we found a significant relationship between balance and aerobic capacity $(\mathrm{P}<0.05)$. We didn't found a significant relationship between balance and aerobic capacity for female athletes $(\mathrm{P}>0.05)$. Also, we didn't found a significant relationship between balance and aerobic capacity for male athletes $(\mathrm{P}>0.05)$. In conclusion, it was considered that due to gender differences in the relationship between balance and aerobic capacity. However, it was said that no differences between Athletes (female and male as separate) with the same physical characteristics.
\end{abstract}

Keywords: Adolescent, aerobic capacity, athletes, balance.

\section{INTRODUCTION}

Exercise and sport can be regarded as effective means for individuals in life quality. However, ones who have sedentary life in society suffer from losses of basic motor characteristics such as power, speed, and endurance in time. Sedentary life cannot protect basic motor characteristics of body with movements necessary for carrying out daily works. The way for protecting or developing this will surely be to do exercise (22). Aerobics or anaerobic energy metabolism influences many motor characteristics of our body with sport and exercise. Additionally, positive changes are expected in body fat rate and body composition with regular aerobic activities. Trainings represent important increases in motor skill development as well $(6,10,11)$. In healthy sedentary individuals, physical activity is a factor which reduces based on age and makes aerobic capacity fall (17). In sport branches the repetitive number of one movement becomes much more, in team sport branches rest intervals are essential, rapid repetitions associated with a high aerobic capacity is very significant (3). In sportive branches requiring high endurance $\mathrm{MaxVO}_{2}$ is very important too (9). Body always gives oxygen to organism much more than it needs. For this reason, it is essential to increase $\mathrm{MaxVO}_{2}$ by doing trainings. An increase of $10 \%$ in $\mathrm{MaxVO}_{2}$ requires doing trainings for 2 or 3 months (19). For the determination of maximal aerobic capacity, $\mathrm{MaxVO}_{2}$ test is a valid and reliable test. High aerobic capacity in any person depends on the oxygen amount per unit used by one. If any sportsman shows a good performance in endurance sport branches, this one is based on the high oxygen consumption level. This is provided with regular trainings (1). Balance is a capability for keeping body weight center of body in supporting surface and maintaining this situation. Balance is very important for anyone to move enough and efficiently at different positions without falling (5). In order to keep body balanced, there are three factors; gravity center, gravity line and supporting surface. The gravity center is in front of the second sacral vertebra in any person with a vertical posture. The gravity center changes in one's position and replaces with movements. Gravity line is a line which passes in the gravity center; its direction is towards the earth center. This line starts from vertex in any person standing steadying, passes over mastoid process, right in front of shoulder joint, through hip joint, right in front of 
knee joint center and in front of ankle joint. Supporting surface is a region including all points any object touches on and found between these points. It is a space between outer parts of feet, heels and toes in any person standing. The point which in gravity line crosses on the ground in balanced position is included into supporting surface (2). The current study aimed to examine relationship between balance and aerobic capacity in adolescent athletes.

\section{MATERIALS \& METHODS}

Total fifty athletes that is twenty five female and twenty five male volunteered to participate in this study after having all risks explained to them before the investigation. Male athletes (age means; $17.12 \pm 0.83$ years, height means; $172.28 \pm 7.66 \mathrm{~cm}$, body weight means; $64.96 \pm 9.21 \mathrm{~kg}$ ). Female athletes (age means; $16.80 \pm 0.82$ years, height means; $162.36 \pm 6.24 \mathrm{~cm}$, body weight means; $53.76 \pm 5.88 \mathrm{~kg}$ ). Prior to data collection, all participants signed a university approved consent form. After receiving a detailed explanation of the study's benefits and risks, all subject signed an informed consent document that was approved by the local ethics committee. None of the subjects reported any medical or orthopedic problems that would compromise his participation and performance in the study. Measurements were taken the indoor at high school of Yahya Kemal Beyatl. The athletes' height was measured with an instrument sensitive to $1 \mathrm{~mm}$ (8). Their body weight was measured with participants dressed in only shorts (and no shoes) with a weight-bridge sensitive up to $20 \mathrm{~g}$ (8).

\section{Aerobic capacity test}

Athletes were required to run between two lines $20 \mathrm{~m}$ apart, while keeping the pace with audio signals emitted from a pre-recorded CD. The initial speed was $8.5 \mathrm{~km} / \mathrm{h}$, which was increased by $0.5 \mathrm{~km} / \mathrm{h}$ per minute ( $1 \mathrm{~min}$ equal one stage). Athletes were instructed to run in a straight line, to pivot on completing a shuttle, and to pace themselves in accordance with the audio signals. The test was finished when the participant failed to reach the end lines concurrent with the audio signals on two consecutive occasions. Otherwise, the test ended when the subject stopped because of fatigue. All measurements were carried out under standardized conditions on an indoor rubber floored gymnasium. The participants were encouraged to keep running as long as possible throughout the course of the test. Aerobic capacity was forecasted by the number of shuttles on forecast table (20).

\section{Flamingo balance test}

Postural balance control was evaluated using the single-legged Flamingo balance test. Athletes were instructed to stand with their eyes open on one leg on a 1-inch-wide, 11/2-inch-high and 20-inch-long bar while the free leg was flexed at the knee joint and held at the ankle joint close to the buttocks. One minute of stance was performed and the number of falls were counted and used as a measure of postural balance. One trial was performed for each leg interspersed by $30 \mathrm{~s}$ of rest. A 1-minute period of familiarization was performed prior to all tests (20).

\section{Statistical Analysis}

Dependent variables for raw data were calculated as means and SD. Pearson coefficients of correlation were used to examine associations between aerobic capacity and balance. It was used regression analysis for effect of aerobic capacity on balance. Alpha was set at .05 for each correlation and regression test.

\section{RESULTS}

Table 1. Data summary for the female and male athletes.

\begin{tabular}{|c|c|c|c|c|}
\hline \multirow{2}{*}{ Variables } & \multicolumn{2}{|c|}{ Male $(n=25)$} & \multicolumn{2}{|c|}{ Female $(n=25)$} \\
\hline & Mean & $\mathrm{SD}$ & Mean & $\mathrm{SD}$ \\
\hline Age (year) & 17.12 & 0.83 & 16.80 & 0.82 \\
\hline Height (cm) & 172.28 & 7.66 & 162.36 & 6.24 \\
\hline Body weight (kg) & 64.96 & 9.21 & 53.76 & 5.88 \\
\hline $\begin{array}{l}\mathrm{MaxVO}_{2} \\
(\mathrm{ml} / \mathrm{kg} / \mathrm{min})\end{array}$ & 41.16 & 5.81 & 32.57 & 4.96 \\
\hline Balance & 6.72 & 4.27 & 12.00 & 4.57 \\
\hline
\end{tabular}

As shown in Table 1, the mean (SD) age is $17.12 \pm 0.83$ (years), height is $172.28 \pm 7.66(\mathrm{~cm})$, body weight is $64.96 \pm 9.21(\mathrm{~kg}), \mathrm{MaxVO}_{2}$ is $41.66 \pm 5.81$ $\mathrm{ml} / \mathrm{kg} / \mathrm{dk}$, and balance score is $6.72 \pm 4.27$ for the male athletes; the mean (SD) age is $16.80 \pm 0.82$ (years), height is $162.36 \pm 6.24(\mathrm{~cm})$, body weight is $53.76 \pm 5.88$ (kg), $\mathrm{MaxVO}_{2}$ is $32.57 \pm 4.96 \mathrm{ml} / \mathrm{kg} / \mathrm{min}$, and balance score is $12.00 \pm 4.57$ for the female athletes.

As shown Table 2, when comparison of the aerobic capacity and balance performance according to gender, $\mathrm{MaxVO}_{2}$ of male was higher than female $(\mathrm{P}<0.05)$. On the other hand, balance in female was better than male $(\mathrm{P}<0.05)$. 
Table 2. A comparison of the aerobic capacity and balance performance according to gender.

\begin{tabular}{lllcccc}
\hline Variables & Gender & $\mathrm{N}$ & Mean & $\mathrm{SD}$ & $\mathrm{t}$ & $P$ \\
\hline \multirow{2}{*}{$\mathrm{MaxV0}_{2}(\mathrm{ml} / \mathrm{kg} / \mathrm{dk})$} & Male & 25 & 41.1640 & 5.81291 & 5.623 & $0.000^{*}$ \\
& Female & 25 & 32.5680 & 4.96334 & & \\
Balance & Male & 25 & 6.7200 & 4.26732 & 4.221 & $0.000^{*}$ \\
& Female & 25 & 12.0000 & 4.57347 & & \\
& & & & & & \\
\hline
\end{tabular}

${ }^{*} \mathrm{p}<0.05$

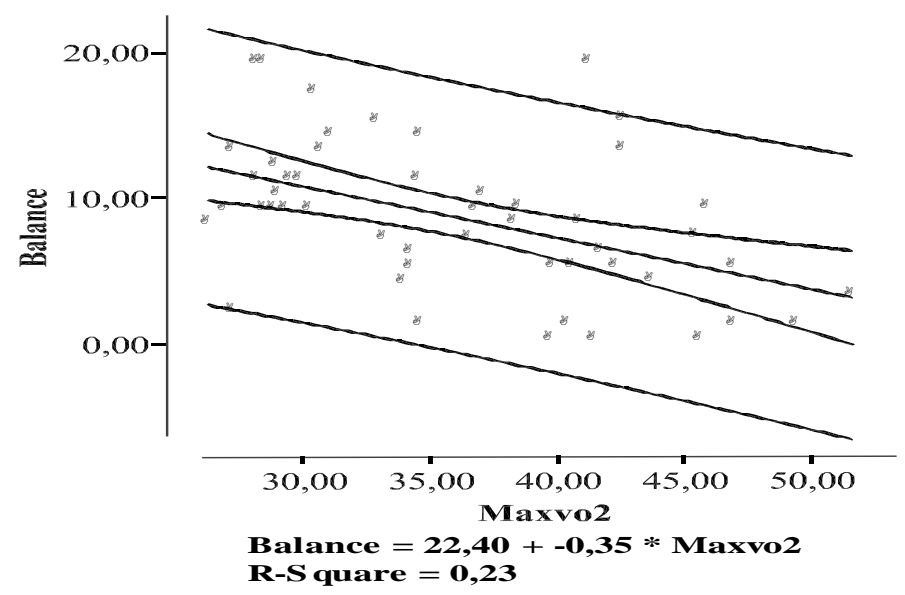

Figure 1. Regression analysis between balance and $\mathrm{MaxVO} 2$ for all athletes.
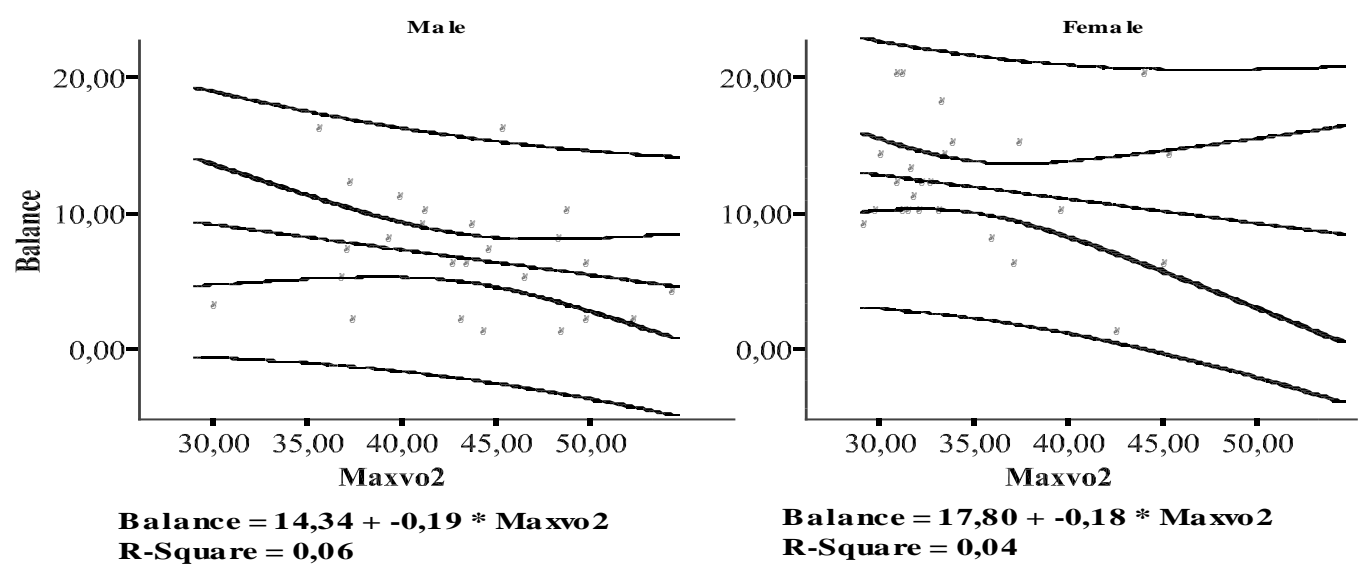

Figure 2. Regression analysis between balance and $\mathrm{MaxVO}_{2}$ in both male and female.

As shown Figure 1, balance was affected to seem $35 \%$ by $\mathrm{MaxVO}_{2}$ in male and female. There was a significant negative relationship between $\mathrm{MaxVO}_{2}$ and balance score in male and female $\left(\mathrm{R}^{2}=0.226 ; \mathrm{P}>0.05\right)$.

As shown Figure 2, balance was affected to seem $19 \%$ by $\mathrm{MaxVO}_{2}$ in male. Also, balance was affected to seem $18 \%$ by $\mathrm{MaxVO}_{2}$ in female. But those results weren't a significant relationship between $\mathrm{MaxVO}_{2}$ and balance score in both male $\left(R^{2}=0,064, \quad p=0.224>0.05\right)$ and female $\left(R^{2}=0.037\right.$, $\mathrm{p}=0.355>0.05$ ).

\section{DISCUSSION}

Within this study aimed at studying the relation between $\mathrm{MaxVO}_{2}$ levels and balance scores of young sportsmen, the aerobic capacity values 
were found to be $41.16 \pm 5.81(\mathrm{ml} / \mathrm{kg} / \mathrm{min})$ in male sportsmen, $32.56 \pm 4.96(\mathrm{ml} / \mathrm{kg} / \mathrm{min})$ in female sportsmen $(\mathrm{P}<0.05)$ on average. Flamingo balance test scores were estimated to be $6.72 \pm 4.27$ in males, $12.00 \pm 4.57$ in females $(\mathrm{p}<0.05)$ on average. Any significant relation was not found between aerobic capacities and balance scores in female and male sportsmen ( $\mathrm{P}>0.05)$. A good balance is necessary for performing physical activities healthily and regularly. This is provided with contributions of muscle power (15). There are many studies in literature which suggest that males have a better balance than females $(12,14)$. Butler et al. (4) determined in their study related with the assessment of balance and walking ability that males were better rather than females. Swanenburg et al. (16) stated that the risk factor of fall in females was higher than males. Balance scores concerning the females mentioned in this study are parallel with the results of the relevant studies in literature. According to the results of regression analysis about the effects of $\mathrm{MaxVO}_{2}$ value on balance in males and females within our research; the $\mathrm{MaxVO}_{2}$ value affected balance at $35 \%$ and the regressive relation between aerobic capacity and balance was negatively at medium level and significant as well $\left(\mathrm{R}^{2}=0.226 ; \mathrm{P}>0.05\right)$. In other words, a reversible relation is a matter of subject between aerobic capacities and balance scores. A certain increase in aerobic capacity leads to improvement in balance. When we analyze the effects of $\mathrm{MaxVO}_{2}$ value on balance in males and females separately here, this one had effects of $19 \%$ in males, $18 \%$ in females. The regressive relation between aerobic capacity and balance score was negative, weak and insignificant in males and females $(\mathrm{P}>0.05)$. Depending on many reasons, balance disorders are observed. Movement ranges and limitations may cause decreases in accessory movements in joints, imbalances in muscle length, depending on this postural and movement pattern changes. Weakness and loss of endurance in muscles may contribute to changes in movement patterns (5). Exercises aimed at strengthening upper and lower limbs and body muscles are beneficial for controlling balance and posture. Males perform a better balance than females, which clears that they have more powerful muscle structures $(7,13)$. In our study females had worse scores in overall tests. These results comply with the literature, that is to say, females have a weaker balance than males. Because muscle power is quite important for keeping balance, males have higher muscle power, which makes them show better balance performances (21). But some studies which cannot find any differences between balance and fall are available in literature (18).

In conclusion, relations between aerobic capacity and balance draw attention when examining all of sportsmen without making any sexual discrimination. But there is no relation when dealing with aerobic capacity and balance scores in males and females under the same sex. Thus, this situation can be considered to result from the same sex with similar physical characteristics.

\section{REFERENCES}

1. Akgün N. Egzersiz ve Fizyolojisi. 5. Baskı, İzmir: Ege Üniversitesi Basımevi, 1994.

2. Akman MN. Biyomekaniğin temel ilkeleri. Beyazova $\mathrm{M}$, Kutsal YG (Editörler). Fiziksel Tip ve Rehabilitasyonda Günes Kitabevi, Ankara, 2011.

3. Bompa TO. Dönemleme Antrenman Kuramı ve Yöntemi. 2. Baskı, Ankara, Dumat Ofset, 2003.

4. Butler AA, Menant JC, Tiedemann AC, Lord SR. Age and gender differences in seven tests of functional mobility. J Neuroeng Rehabil, 2009; 6:31.

5. Diraçoğlu D. Denge ve koordinasyon ölçümleri. 2. Romatoloji Ve Tibbi Rehabilitasyon Günleri, "Ölçme Ve Değerlendirme" Sempozyumu Özet Kitabı, Ankara, 2008.

6. Donnely JE, Hill JO, Jacobsen DJ, Potteiger J, Sullivan DK, \& Johnson SL. Effects of a 16-month randomized controlled exercise trial on body weight and composition in young, overweight men and women. Arch Intern Med, 2003; 163, 1343-50.

7. Gardner MM, Buchner DM, Robertson MC, Campell AJ. Practical implementation of an exercise-based falls prevention programme. Age Aging 2001; 30: 77-83.

8. Gordon C, Chumlea C, Roche AF. Stature, recumbent length and weight. In (Eds) Lohman TG, Roche AF, Marorell R. Anthropometric standardization reference manual. Illinois: Human Kinetics Books, 1988.

9. Günay E. Düzenli yapılan yüzme antrenmanlarının çocukların bazı fiziksel ve fizyolojik parametreleri üzerine etkisi. Gazi Üniversitesi, Sağlık Bilimleri Enstitüsü Yüksek Lisans Tezi, Ankara. 2007.

10. Hockey RV. Physical fitness, the pathway to healthful living. Saint Louis: Mosby Company, 1977.

11. Hrysomallis C. Balance ability and athletic performance. Sports Medicine, 2011; 41 (3), 221-33.

12. Karataş GK, Maral I. Ankara-Gölbaşı ilçesinde geriatrik popülasyonda 6 aylık dönemde düşme sıklığı ve düşme için risk faktörleri. Turk J Geriatr, 2001; 4(4): 152-58.

13. Kammerlind AS, Hakansson JK, Skogsberg MC. Effects of balance training in elderly people with nonperipheral vertigo and unsteadiness. Clin Rehabil 2001; 15: 463-70.

14. Mengi G, Çavdaroğlu B. Bor fizik tedavi ve rehabilitasyon hastanesine başvuran yaşlilarda denge ve yürüme performansı. FTR Bil Der, 2011; 14: 39-4. 
15. Sturnieks DL, St George R, Lord SR. Balance disorders in the elderly. Neurophysiol Clin, 2008; 38: 467-78.

16. Swanenburg J, de Bruin ED, Uebelhart D, Mulder T. Falls prediction in elderly people: a 1-year prospective study. Gait Posture 2010; 31: 317-21.

17. Özkayar N, Arıoğul S. Yaşlanma ile meydana gelen fizyolojik değişiklikler. İç Hastalıkları Dergisi, 2007; 14(1): 18-26.

18. Shumway-Cook A, Baldwin M, Polissar NL, Gruber W Predicting the probability for falls in community-dwelling older adults. Phys Ther, 1997; 77(8): 812-19.
19. Tamer K. Çeşitli koşu programlarının aerobik, anaerobik güç ve akciğer fonksiyonlarına etkileriyle ilişki düzeylerinin belirlenmesi. Performans Dergisi, 1.3 1995; 1(3): 32-39.

20. Tamer K. Sporda fiziksel-fizyolojik performansın ölçülmesi ve değerlendirilmesi. Bağırgan Yayımevi, 2000.

21. Yağız-On A, Beyazova M. Normal yürüme: Tanımı, nitelikleri ve görsel değerlendirilmesi, Sarıca Y (Editor). Postür, denge ve yürüme bozukluklarında. Ankara: Güneş Tip Kitabevleri. 2008; s.19-34.

22. Zorba, E. Fiziksel Uygunluk Ankara: Gazi Kitapevi, 2001. 